\title{
The Lark or Lavrock
}

By LAVONIA STOCKELBACH, Verona, New Jersey

Editor's Note: Mrs. Stockelbach, artist and author, is a Canadain by birth although she has lived n New Jersey for a number of years. Mrs. Stockelbach, as may be surmised from her article, has done a lot of travelling. For a review of her book, The Birds of Shakespear, see page 185.

Of the many delightful surprises n my northwestern pilgrimage this year none was greater than to see and hear the skylark in British Columbia. I had heard that it had pecome established there, but I did not quite believe that I would have he good fortune to meet Alauda urvensis. However, a kind lady was sure she could find him for me, and falled early one morring in the middle of May to drive me the few niles from the centre of the city of Victoria to a likely field.

And there, suddenly, as the car vent along a country road, was the kylark singing his heart out on a ence post not twenty-five feet away. For more than twelve minutes we istened. It was not necessary to be specially quiet, because the reason or the outburst was a rival skylark on another post across the narrow oad. Although I had heard the kylark many times in Europe, this vas the first time I had ever heard ne singing perched on a fence post. However, on my return home I came cross a note to the effect that they re known to sing from such a perch. their hind claws are very long and traight and they are thus prevented rom clasping small twigs but may se larger branches. But I associate kylariks, except when they are in light, chiefly with the ground.

0 , here the gentle lark, weary of rest, rom his moist cabinet mounts up on high nd wakes the morning, from whose silver breast he sun ariseth in his majesty;

Who doth the world so gloriously behold, That cedar-tops and hills seem burnished gold. - (Venus and Adonis)

This particular lark may have rakened the morning-I was not up $t$ such an unearthly hour of May check-but at ten o'clock he aparently had only one motive, to usting his rival. We should have ad a movie camera to portray the ulsating of the tiny throat feathers ke an animated fichu, as he faced us. It has been noted that larks, as do ther birds, sing differently in difprent countries and indeed in difrent sections of the same country, ut whether $\mathrm{y}_{1}: \mathrm{u}$ hear him in March ith Freza Stark on the island of

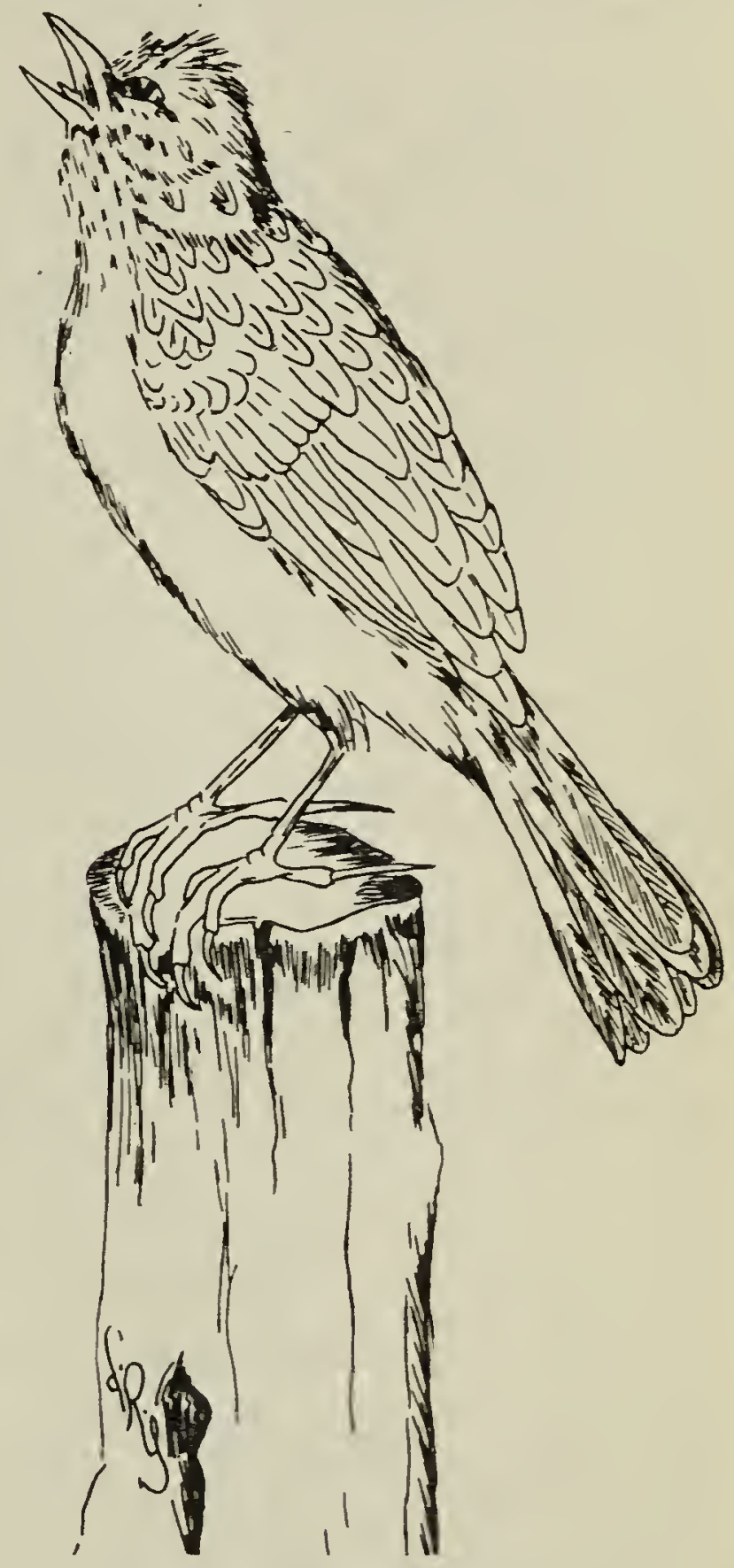

Failichah, in the Persian Gulf, on Beachy Head in England, or in Jutland, Denmark, you could never mistake the lark's song. The first loud clangorous notes can startle one if the bird is flushed close by, and it is only after he has attained a certain height that the full glory of his song is manifest.

P. H. Warning of Denmark lays stress upon the careful building lip of the lark's song: the compositionsometimes a long composition-has well arranged themes, with varied re-shapings, but always it has a definite framework. There are not many notes: an octave comprises the whole gamut, so his song has not much colour variation, but its clear 
tones and silvery trill make up for that lack.

It is indeed pleasant for Canadians to have this bond of union with Europe, and especially with England, the land of Shakespeare. In the more than six hundred references to birds in Shakespeare's plays, a score refer to the skylark. In Cymbeline, the delightful song "Hark, Hark! the Lark at Heaven's gate sings" has enchanted thousands of listeners, though Imogen herself vouchsafed no notice. In Henry V it sounds so natural and commonplace to have the Dauphin say: "from the rising of the lark to the lodging of the lamb."

As a small boy Shakespeare noted, as have all who know larks, that the first sound as he rises is loud and rather harsh, so in King Lear we read "The shrill-gorged lark so far cannot be seen or heard." In The Merchant of Venice, Portia says "the crow doth sing as sweetly as the lark when neither is attended," and that humorous statement none can gainsay.

Bird-song seems to have been in every fibre of the man. In $A$ Midsummer Night's Dream Helena says enviously to Hermia "your tongue's sweet air is more tuneable than lark to shepherd's ear," and the tragic note is struck in Richard II with:
Down Court! Down King!

For night owls shriek where moun ing larks should sing.

Again, a different note when Troil says to Cressida "the busy day, wake by the lark, hath roused the ribal crows."

Then in that touching scene Romeo and Juliet where Juliet trif to persuade Romeo that he is lister ing to the nightingale, he respond "It was the lark, the herald of th morn - no nightingale - night candles are burnt out and jocund de stands tip-toe on the misty mounta. tops.'

In the fourteenth stanza of $T r$ Passionate Pilgrim, as the frettir sleepless man listens to Philomel the nightingale, singing, he moanin: ly wishes "her lays were tuned lit the lark; for she doth welcome da: light with her ditty, and drives aw: dark dismal-dreaming night."

So all through his life the sme town boy recalls the birds he kne and loved in his youth. These a: only a $f \in w$ of the hundreds of refe ences showing an accurate knowled! of those that came under Shak speare's own observation, but th encourage one to take greater noti of those within one's own neighbo hood.

\section{Besant - A Memory}

\section{By ROSE McLAUGHLIN, Indian Head}

Betiveen Caron and Mortlach, Saskatchewan, there lies a scrubby sitretch of pasture and wasteland, its choppy hillsides pitted with the sandy scars of eroding winds, and its brushy flats threaded by a trickle which swells into a flood in years of bountiful rainfall. Traversed today by the mainline of the C.N.R., and by Trans-Canada highways and skyways, it was likewise in the stream of man's earliest migrations, for this is the region known as Besant, happy hunting ground of our archaeologists.

In the Blue Jay I read of their comings and goings in Besant, and wonder nostalgically if their finds include a sheltered glade carpeted with lawn grass and tiny pink and white clover. Do they have any scientific theory for its presence in that wild anci lonely spot? And do they spread their picnic cloth there on the gentle bank by the stream edge, as we have done so often summers past?

To dwellers of the plains, west Mcose Jaw, Besant was a place enchantment where one might fi again all the flora and fauna lost the change-cover to cultivation. De sometimes strayed into the open, a] little gray ground squirrels nibbl furtively at our tossed crusts. Há thorn, chokecherry, and saskato perfumed the air in spring, and su fused it with color in the fall. $T$ profusion of wildflowers was divid by this frustrated naturalist into ty classes: the common ones that ever one knows and the strangers that one knows.

Nowhere have I seen the brev: of cur prairie summer so emphasiz as at Besant. In July when the queens of the summer - lily, ro 